\title{
Clinical significance of antibodies to ribonucleoprotein
}

\author{
MILTON L. COHEN, BRUCE DAWKINS, ROGER L. DAWKINS, \\ AND EVAN T. OWEN \\ From the Departments of Rheumatology and Clinical Immunology, Queen Elizabeth II \\ Medical Centre, and Royal Perth Hospital, Perth, Western Australia
}

SUMMARY Antibodies to ribonucleoprotein (RNP) were detected by an immunofluorescence technique based on the sensitivity of speckled antinuclear antibodies to ribonuclease. These antip bodies were found to identify a group of patients with a consistent set of clinical features, especialli arthritis, swollen hands, Raynaud's phenomenon, and myositis. The presence of anti-RNP antibodies in sera from patients with polymyositis, systemic lupus erythematosus, and systemic sclerosio was also associated with these clinical features. Other studies of the clinical significance of these antibodies support the concept that they appear to identify a group of patients with a distinç clinical condition.

Although various antinuclear antibodies (ANAs) have been recognised for years, the clinical significance of each variety is poorly understood. Antinuclear DNA antibodies detected by multiple techniques are of undoubted value in the recognition and assessment of systemic lupus erythematosus (SLE). Of the patterns delineated by immunofluoresence, nucleolar antinuclear antibodies have been associated with SLE and progressive systemic sclerosis (PSS) and speckled ANAs with SLE, Sjøgren's syndrome, and the more recently described syndrome of mixed connective tissue disease (MCTD). The 'overlap' syndrome shares clinical features of SLE, PSS, and polymyositis and has been characterised serologically by the presence in high titre of antibodies to the ribonucleoprotein component of a saline-soluble extractable nuclear antigen (ENA) prepared from thymus (Sharp et al., 1972).

An important development has been the demonstration that different antibodies may be responsible for the speckled pattern of nuclear fluorescence. These include antibodies to ribonucleoprotein (RNP) (Northway and Tan, 1972), to the Sm antigen (Tan and Kunkel, 1966). and to another antigen identified in Sjøgren's syndrome (Alspaugh and Tan, 1975; Akizuki et al., 1977a). Methods for detecting antibodies to RNP depend on treatment

Accepted for publication 21 March 1978

Correspondence to Dr R. L. Dawkins, Department of Clinical Immunology, Queen Elizabeth II Medical Centre, Nedlands, Western Australia 6009. of the antigen with ribonuclease (RNase) and includg haemagglutination (Sharp et al., 1971), counters immunoelectrophoresis (Kurata and Tan, 1976) and double diffusion (Akizuki et al., 1977b). We haves further developed an immunofluoresence metho $\$$ which relies on the abolition of the speckled patterit of nuclear fluoresence after treatment of the acetones fixed substrate with RNase (Tan and Kunkel, 1966)

In a previous study (Cohen et al., 1977) we examo ined 46 sera with speckled ANA by this immuno fluorescent technique. Two groups of sera were identified: those with titres greater than 1:1000 which fell by a mean 100 -fold after enzyme treatment of the substrate, and those with titres less than $1: 1000$. The clinical features of the 2 groups of patients thus defined were compared. The high titro group had a high prevalence of arthritis, Raynaud phenomenon, swollen hands, sclerodermatous skio. changes, and myositis, and the clinical spectrum resembled that described for MCTD. As it appeared that the immunofluorescent technique was identifying a group of patients similar to those with the antio bodies detected by haemagglutination, the presen study was undertaken to investigate more precisele the clinical significance of these antibodies.

\section{Methods}

\section{DETECTION OF ANTI RNP BY FITC}

The substrate (rat kidney, snap-frozen and cut $4 \mu \mathrm{m}$ thickness) was fixed in acetone (Tan, 196 at room temperature for 10 minutes to minimise the 
elution effect of saline in buffers. After air drying, substrates for enzyme treatment were immersed for 60 minutes at $37^{\circ} \mathrm{C}$ in a solution of ribonuclease $A$ (Worthington Biochemical Corporation) diluted to $4 \mathrm{mg}$ per $100 \mathrm{ml}$ in $0.01 \mathrm{M}$ PBS (pH 7.2) containing $0.4 \mathrm{mM}$ magnesium chloride. The control substrate was similarly fixed, dried, and immersed in the above buffer without RNase. Sera of the appropriate dilutions were added to both control and enzyme treated substrates. After incubation in a moist chamber for 45 minutes the sections were washed twice for 5 minutes in PBS at $\mathrm{pH} 7 \cdot 2$ before addition of fluorescein-conjugated polyvalent antihuman immunoglobulin (Wellcome) at normal working dilutions. After a further 45 minutes' incubation 2 20-minutes washes in PBS at pH 7.2 were performed before the sections were mounted in buffered glycerol at $\mathrm{pH} 8 \cdot 2$. The fluorescence of speckled ANA was read to extinction on an Ortholux epifluorescence microscope using the 1,5 ultraviolet light filter system.

\section{OTHER IMMUNOLOGICAL METHODS}

Rheumatoid factors were detected by Latex (Hyland) and Rheumaton (Denver) kits. Serum IgG, $\operatorname{IgM}, \operatorname{IgA}, \mathrm{C} 3$, and $\mathrm{C} 4$ were measured by radial immunodiffusion (Oxford). Cryoglobulins were sought by collection and separation of sera at $37^{\circ} \mathrm{C}$, before 96-hour storage at $4^{\circ} \mathrm{C}$. Anti-DNA binding was measured by the Farr assay (normal less than $26 \%$ ).

\section{IMMUNODIFF USION}

To detect precipitating antibodies a modification of the Ouchterlony agar gel diffusion was used and essentially followed the method of Tan and Kunkel (1966). Plastic petri dishes $(50 \times 10 \mathrm{~mm})$ were filled with $5 \mathrm{ml}$ of $0.4 \%$ agarose (Sigma Chemical Co.) in phosphate buffered saline at pH $7 \cdot 2,0.01 \mathrm{M}$, with $0 \cdot 1 \%$ sodium azide. The well pattern consisted of 6 outside wells $4 \mathrm{~mm}$ in diameter and a central well $9 \mathrm{~mm}$ in diameter. The reacting diffusion dishes were incubated in a moist chamber at $4^{\circ} \mathrm{C}$ and observed daily for 5 days and then every second day until day 14.

The basic antigen used throughout this series was rabbit thymus (Pel-Freeze Biologicals) extracted overnight at $4^{\circ} \mathrm{C}$ by mixing with $\mathrm{PBS}$ at $\mathrm{pH} 7 \cdot 2$, $0.01 \mathrm{M}$, and standardised at $10 \mathrm{mg} / \mathrm{ml}$ of protein.

Prototype sera which fulfilled criteria according to Akizuki et al. (1977b) of anti-RNP and anti-Sm, that is, reactivity or nonreactivity after antigen treatment with various enzymes and temperatures, and which appeared to have no other detectable antibody to ENA by immunodiffusion, were selected as 'reference' sera to establish identity or nonidentity of precipitin lines with test sera. All test sera were screened at various dilutions and exposed both to treated and non treated antigens.

\section{SERA AND PATIENTS}

Two groups of sera were studied. The first (group A) was identified from the routine laboratory screen for autoantibodies over a 2-year period. Twenty-one such sera were found to have speckled antinuclear antibodies in a titre of 1:1000 or greater. The records of patients from whom these sera were taken were studied to extract clinical features and other laboratory data for correlation with the serum findings. Particular attention was paid to the presence of arthritis, Raynaud's phenomenon, myositis, swollen hands, lymphadenopathy, and hepatosplenomegaly. Abnormal oesophageal motility and diminished pulmonary diffusing capacity were noted. Myositis was considered to be present if a proximal weakness was accompanied by at least one abnormal investigation, namely, raised serum creatine kinate or aldolase, abnormal electromyograph, or abnormal muscle biopsy. Renal asssessment was based on protein and white cell excretion and biopsy where this was performed.

The second group of sera (group B) was obtained from (1) 35 patients with polymyositis according to the criteria of Dawkins (1977); (2) 14 patients with progressive systemic sclerosis; and (3) 26 patients with SLE according to the American Rheumatism Association's preliminary criteria. A similar correlation of serum findings and clinical features was undertaken. The application of the IF technique to sera from patients with SLE is complicated by the different patterns of nuclear fluorescence which may occur, the homogenous and peripheral patterns tending to obscure speckling especially at low titre. The double diffusion technique was therefore used for qualitative detection of anti-RNP antibodies.

\section{Results}

\section{GROUP A SERA}

Titres of the 21 patients with high-titre speckled antinuclear antibodies were found to be markedly sensitive to RNase. The results of differential titring are shown in Table 1 . The reciprocal of titre on control substrate over reciprocal of titre on enzyme-treated substrate ranged from $20000 /$ 400 to $1200 / 5$. The results of the same sera subsequently examined by the double diffusion method are also shown as the reciprocal of titre of antibodies to RNP. Non RNase-sensitive antibodies to ENA are shown when detected.

The clinical and laboratory features of these patients are shown in Table 2 and are compared with results from other series of patients whose sera 
contain a high titre of antibodies to RNP. In the present study there were 7 males and 14 females, their ages ranging from 14 to 80 , with a mean of 40 years. There was a predominance of arthritis,

Table 1 Serological findings in 21 patients with hightitre speckled antinuclear antibodies

\begin{tabular}{lccl}
\hline $\begin{array}{l}\text { Patient } \\
\text { no. }\end{array}$ & $\begin{array}{l}\text { Differential titre of } \\
\text { speckled ANA }\end{array}$ & $\begin{array}{l}\text { Anti-RNP } \\
\text { by double } \\
\text { diffusion }\end{array}$ & $\begin{array}{l}\text { Other anti- } \\
\text { ENA } \\
\text { detected }\end{array}$ \\
\hline 1 & $20000: 400$ & 64 & - \\
2 & $10000: 20$ & 256 & - \\
3 & $8000: 5$ & 128 & - \\
4 & $8000: 60$ & 64 & Sm \\
5 & $6000: 5$ & 64 & NI \\
6 & $>5120: 5$ & 128 & - \\
7 & $5000: 20$ & 32 & - \\
8 & $4000: 300$ & 32 & Sm \\
9 & $3000: 10$ & - & NI \\
10 & $3000: 10$ & 4 & - \\
11 & $3000: 20$ & 16 & - \\
12 & $2500: 300$ & 16 & - \\
13 & $2000: 5$ & ND & - \\
14 & $2000: 5$ & ND & - \\
15 & $2000: 40$ & - & NI \\
16 & $1200: 5$ & - & NI \\
17 & $1200: 5$ & 1 & - \\
18 & $1200: 10$ & 1 & - \\
19 & $1200: 20$ & ND & - \\
20 & $1200: 80$ & 1 & NI \\
21 & $1000: 300$ & & \\
\hline
\end{tabular}

$\mathrm{NI}=$ not identified. $\mathrm{ND}=$ not done.
Raynaud's phenomenon and swollen hands. Although half the patients had no renal abnormality, 7 had increased orinary excretion of white cellso and in 5 a renal biopsy was abnormal (one minimalo change on light microscopy, 2 mesangioproliferative

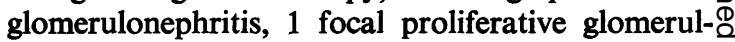
onephritis, 1 chronic glomerulonephritis). No patient had proteinuria, and only 1 had mild renal failure. The neurological abnormalities in our patients were. a trigeminal neuropathy in 4 patients and a peripheral $\vec{\omega}$ neuropathy in 1 . Three patients had keratoconjunctivitis sicca. A high prevalence of hypergammaglobulinaemia and of positive rheumatoid factor was $\omega$

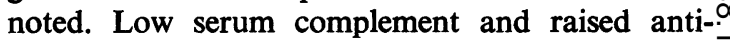
DNA antibodies were uncommon. Those patients $-\overrightarrow{-}$ (Nos. 1, 8, 12, and 21) whose sera had residual titres of speckled ANA greater than 1:100 after ${ }^{3}$ $R$ Nase treatment were not distinguishable on clinical $\vec{T}$ grounds from the group as a whole. As suggested in $\frac{\mathscr{O}}{O}$ Table 1, these residual titres may represent antibodies to the Sm or Sjøgren's-associated antigens.

Fig. 1 shows the association of the main clinical $\vec{\theta}$ features as found in our 21 patients. Arthritis, Raynaud's phenomenon, and swollen hands are strongly associated, as are myositis and trigeminalo neuropathy.

Table 2 Clinical and laboratory features of 21 patients with high-titre speckled antinuclear antibodies sensitive to RNase compared with other series

\begin{tabular}{|c|c|c|c|c|c|}
\hline Author & Present study & $\begin{array}{l}\text { Sharp et al. } \\
(1976)\end{array}$ & $\begin{array}{l}\text { Farber and Bole } \\
(1976)\end{array}$ & $\begin{array}{l}\text { Leibfarth and } \\
\text { Persellin (1976) }\end{array}$ & Parker (1973) \\
\hline Number of patients & 21 & 100 & 17 & 16 & 10 \\
\hline Basis of RNase sensitivity & $\begin{array}{l}\text { Abolition of } \\
\text { fluorescent } \\
\text { speckled } A N A\end{array}$ & $\begin{array}{l}\text { 1000-fold drop } \\
\text { in titre by } H A\end{array}$ & $\begin{array}{l}\text { 50-fold drop } \\
\text { in titre by } H A\end{array}$ & $\begin{array}{l}400 \text {-fold drop } \\
\text { in titre by } H A\end{array}$ & $\begin{array}{l}\text { Abolition of } \\
\text { agarose } \\
\text { precipitation }\end{array}$ \\
\hline Clinical & & o & $\%$ & & $\%$ \\
\hline Arthritis & 86 & 95 & 88 & 75 & 90 \\
\hline Swollen hands & 55 & 66 & 53 & 38 & 30 \\
\hline Raynaud's phenomenon & 90 & 85 & 76 & 50 & 100 \\
\hline Myositis & 33 & 63 & 53 & 31 & 40 \\
\hline Sclerodermatous changes & 29 & 33 & 44 & & - \\
\hline Telangiectases & 5 & - & - & 38 & - \\
\hline Vasculitis & 38 & 30 & 29 & & - \\
\hline Abnormal oesophageal mobility & $3 / 7$ & $50 / 75$ & 35 & 31 & - \\
\hline Diminished pulmonary diffusion & $4 / 9$ & $29 / 43$ & $5 / 5$ & 44 & - \\
\hline Lymphadenopathy & 24 & 39 & 18 & 31 & - \\
\hline Hepatosplenmegaly & 10 & 19 & 12 & - & - \\
\hline Fever & 19 & 33 & 41 & 94 & - \\
\hline Serositis & 19 & 27 & 53 & 50 & - \\
\hline Renal abnormality & 48 & 10 & - & - & - \\
\hline Neurological abnormality & 23 & 10 & - & - & - \\
\hline \multicolumn{6}{|l|}{ Laboratory } \\
\hline Speckled ANA & $(\mathbf{1 0 0 )}$ & 97 & $11 / 13$ & 100 & 100 \\
\hline Raised anti-DNA binding & 14 & 12 & 35 & $\mathbf{0}$ & - \\
\hline Positive rheumatoid factor & & $34 / 62$ & 100 & 62 & - \\
\hline Hypergammaglobulinaemia & & 73 & $13 / 15$ & 81 & - \\
\hline Low C3 & & $3 / 70$ & $5 / 12$ & 44 & 0 \\
\hline Cryoglobulinaemia & $2 / 19$ & - & - & - & - \\
\hline Anaemia & 10 & 41 & 71 & 25 & - \\
\hline Leucopenia & 10 & 35 & 71 & 12 & 90 \\
\hline
\end{tabular}


Clinical teatures in 21 patients with anti-RNP antibodies

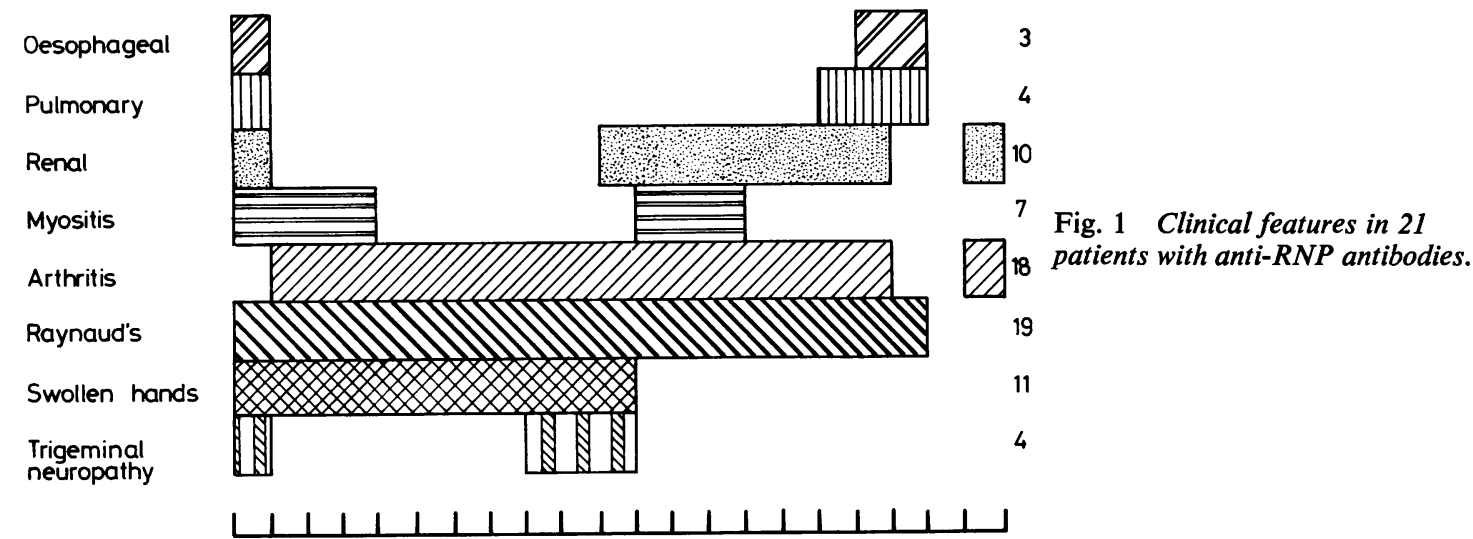

\section{GROUP B SERA}

Of 35 patients with polymyositis 2 had sera containing speckled ANA but only 1 had a high titre of antiRNP. This patient was clinically different, with Raynaud's phenomenon, swollen hands, and oesophageal involvement as well as myositis. Of 14 patients with systemic sclerosis 5 had speckled ANA, of whom 3 had high-titre anti-RNP. One has frank myositis as well as features of PSS; a second had myositis, has developed synovitis, and is showing improvement of grossly involved skin; the third is at present clinically indistinguishable from classical PSS. By the double diffusion technique 2 of 26 SLE sera showed a precipitin line believed to be antiRNP. Both patients have marked Raynaud's phenonmenon, and one has renal changes atypical for lupus with minimal light microscopy changes and deposits of $\operatorname{IgA}$ on the glomerular basement membrane. The other has continuing cutaneous vasculitis, membranous glomerulonephritis with vascular as well as glomerular immune complex deposits, and an antiribosomal antibody on routine serum immunofluorescence.

\section{Discussion}

Akizuki et al. (1977b) have compared immunofluorescence, haemagglutination, complement fixation, and immunodiffusion as methods for detecting antibodies to soluble nuclear antigens. These authors imply that elution of antigen renders the IF technique unreliable. The method described above does suffer from some disadvantages, but it does appear to provide clinically useful information with advantages in simplicity, time, and cost. It is not yet clear whether the greatest practical value is provided by the titre after treatment with buffer alone or the differential titre obtained by comparing buffer and
RNase. It should be emphasised that the present approach depends on the use of the titre of speckled rather than other types of ANA. The method was reproducible both on repeat examinations of the same serum and on examination of serial sera. Furthermore, the results of the double diffusion and immunofluorescence techniques correlate well, suggesting that they may detect the same anti-RNP antibodies. Other methods will help in classifying ANAs more completely.

We have shown that antibodies to RNP identify a group of patients with a clinical and laboratory profile similar to that associated with 'MCTD' (Sharp et al., 1972, 1976; Parker, 1973; Farber and Bole, 1976; Leibfarth and Persellin, 1976). More specifically, all reports show that these antibodies appear to correlate with certain clinical features, in particular arthritis, Raynaud's phenomenon, myositis, and swollen hands. While renal disease appears to be uncommon, minor abnormalities in renal function tests may be associated with antibodies to RNP.

Reichlin and Mattioli (1972) noted that antiRNP antibodies in a group of clinically defined SLE patients identified a subgroup with a paucity of serious renal disease. This subgroup also had an increased prevalence of Raynaud's phenomenon, myositis, and serositis compared with the subgroup of SLE patients lacking these antibodies. Arthritis and skin rash were equally prevalent in both groups. Parker (1973) found that the presence of anti-RNP in SLE patients was a marker for arthralgia, myositis, and Raynaud's phenomenon. Anti-RNP in our group of SLE sera identified 2 patients with marked Raynaud's symptoms and atypical renal features.

Anti-RNP antibodies in 2 of our systemic sclerosis patients were markers for myositis in both and synovitis in one. Parker (1973) noted that 2 out of 16 
patients were scleroderma had antibodies to RNP: one had raised serum muscle enzymes, the other had had myositis, Coombs-positive haemolytic anaemia, and a softening of skin changes on corticosteroids. Chihara et al. (1977) found that the 8 of 33 patients with systemic sclerosis who had these antibodies had a higher prevalence of myositis, trigeminal neuropathy, and sicca symptoms. In our polymyositis patient these antibodies appeared as a marker for Raynaud's phenomenon and swollen hands.

Immunofluorescence screening can provide a simple method for detecting antibodies to RNP. The presence of these antibodies appears to correlate with a consistent set of clinical features and may be useful in identifying groups of patients whose clinical condition is distinct from that of others lacking such markers.

\section{References}

Akizuki, M., Powers, R. Jr., and Holman, H. R. (1977a). A soluble acidic protein of the cell nucleus which reacts with serum from patients with systemic lupus erythematosus and Sjøgren's syndrome. Journal of Clinical Investigation, 59, 264-272.

Akizuki, M., Powers, R. Jr., and Holman, H. R. (1977b). Comparative study of immunologic methods for demonstration of antibodies to soluble nuclear antigens. Arthritis and Rheumatism, 20, 693-701.

Alspaugh, M. A., and Tan, E. M. (1975). Antibodies to cellular antigens in Sjøgren's syndrome. Journal of Clinical Investigation, 55, 1067-1073.

Chihara, T., Dorsch, C. A., Arnett, F. C. Jr., Shilman, L. E., and Berens, M. B. (1977). Antibodies to extractable nuclear antigen in progressive systemic sclerosis. XIV International Congress of Rheumatology, San Francisco. Abstract 658.

Cohen, M. L., Dawkins, R. L., and Dawkins, B. (1977). Sensitivity of speckled antinuclear factor to ribonuclease as a diagnostic test for the mixed connective tissue disease syndrome. Australian and New Zealand Journal of Medicine, 7, 460.

Dawkins, R. L. (1977). Muscle Disease, in Immunology in Medicine, p. 841. Edited by E. J. Holborow and W. G. Reeves. Academic Press: London.
Farber, S. J., and Bole, G. G. (1976). Antibodies to components of extractable nuclear antigen-clinical character $\overline{\bar{\sigma}}$ istics of patients. Archives of Internal Medicine, 136, 425431.

Kurata, N., and Tan, E. M. (1976). Identification of anti을 bodies to nuclear acidic antigens by counterimmuno $\frac{\rho}{5}$ electrophoresis. Arthritis and Rheumatism, 19, 574-580

Leibfarth, J. H., and Persellin, R. H. (1976). Characteristics of patients with serum antibodies to extractable nuclean antigens. Arthritis and Rheumatism, 19, 851-856.

Northway, J. D., and Tan, E. M. (1972). Differentiation of antinuclear antibodies giving speckled staining patternsin immunofluorescence. Clinical Immunology and Immunow pathology, 1, 140-154.

Parker, M. D. (1973). Ribonucleoprotein antibodies: fre quency and clinical significance in systemic lupus eryew thematosus, scleroderma and mixed connective tissue disease. Journal of Laboratory and Clinical Medicine, 82, 769-775.

Reichlin, M., and Mattioli, M. (1972). Correlation of precipitin reaction to an RNA protein antigen and a low prevalence of nephritis in patients with systemic lupus erythematosus. New England Journal of Medicine, 286 908-911.

Sharp, G. C., Irvin, W. S., La Roque, R. L., Velez, C Daly, V., Kaiser, A. D., and Holman, H. R. (1971) Association of autoantibodies to different nuclear antigens with clinical patterns of rheumatic disease and responsiveco ness to therapy. Journal of Clinical Investigation, 5000 350-359.

Sharp, G. C., Irvin, W. S., Tan, E. M., Gould, R. R., and Holman, H. R. (1972). Mixed connective tissue diseasean apparently distinct rheumatic diseases syndrome associated with a specific antibody to an extractable nuclear antigen (HNA). American Journal of Medicine $52,148-159$.

Sharp, G. C., Irvin, W. S., May, C. M., Holman, H. R McDuffie, F. C., Hess, E. V., and Schmid, F. R. (1976) Association of antibodies to ribonucleoprotein and $\mathrm{Sm}$ antigens with mixed connective tissue disease. systemi lupus erythematosus and other rheumatic diseases, $\mathrm{Ne}$ England Journal of Medicine, 295, 1149-1154.

Tan, E. M., and Kunkel, H. G., (1966). Characteristics of $\frac{0}{5}$ soluble nuclear antigen precipitating with sera of patients with systemic lupus erythematosus. Journal of Immunos $\log y, 96,464-471$.

Tan, E. M. (1967). Relationship of nuclear staining pattern with precipitating antibodies in systemic lupus erythema tosus. Journal of Laboratory and Clinical Medicine, 70 800-812. 